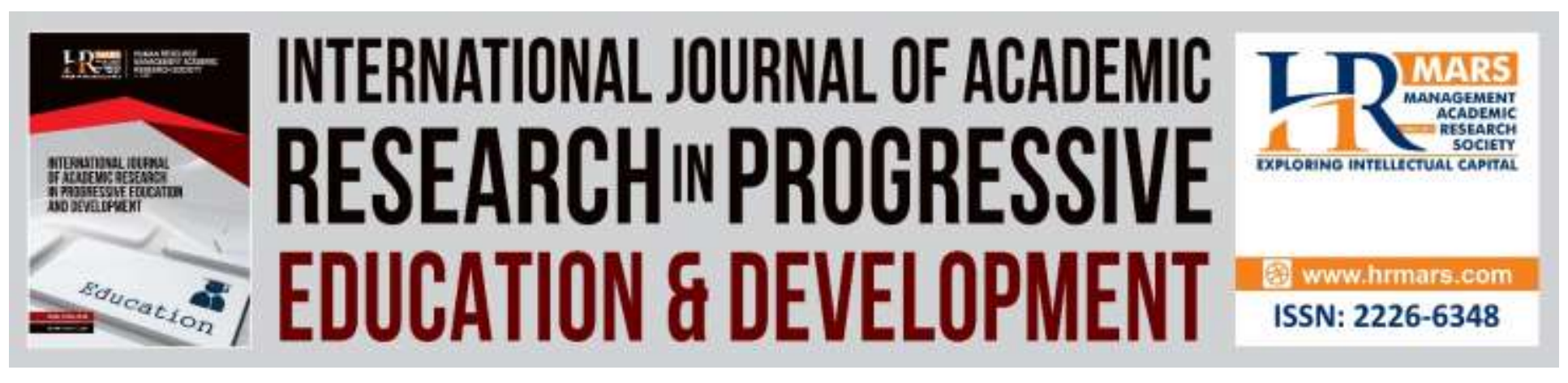

\title{
The Effect of Ownership Structure on Firm Performance among Jordanian Public Shareholders Companies: Board Independence as a Moderating Variable
}

Mohammad Mustafa Dakhlallh, Nik MohdNorfadzilah Nik Mohd Rashid, Wan Amalina Wan Abdullah, Abdalrahman Mustafa Dakhlallh

To Link this Article: http://dx.doi.org/10.6007/IJARPED/v8-i3/6212

DOI: $10.6007 /$ IJARPED/v8-i3/6212

Received: 04 June 2019, Revised: 26 June 2019, Accepted: 13 July 2019

Published Online: 28 August 2019

In-Text Citation: (Dakhlallh, Rashid, Abdullah, \& Dakhlallh, 2019)

To Cite this Article: Dakhlallh, M. M., Rashid, N. M. N. M., Abdullah, W. A. W., \& Dakhlallh, A. M. (2019). The Effect of Ownership Structure on Firm Performance among Jordanian Public Shareholders Companies: Board Independence as a Moderating Variable. International Journal of Academic Research in Progressive Education and Development, 8(3), 13-31.

Copyright: (c) 2019 The Author(s)

Published by Human Resource Management Academic Research Society (www.hrmars.com)

This article is published under the Creative Commons Attribution (CC BY 4.0) license. Anyone may reproduce, distribute, translate and create derivative works of this article (for both commercial and non-commercial purposes), subject to full attribution to the original publication and authors. The full terms of this license may be seen at: http://creativecommons.org/licences/by/4.0/legalcode

Vol. 8(3) 2019, Pg. 13-31

http://hrmars.com/index.php/pages/detail/IJARPED

JOURNAL HOMEPAGE

Full Terms \& Conditions of access and use can be found athttp://hrmars.com/index.php/pages/detail/publication-ethics 


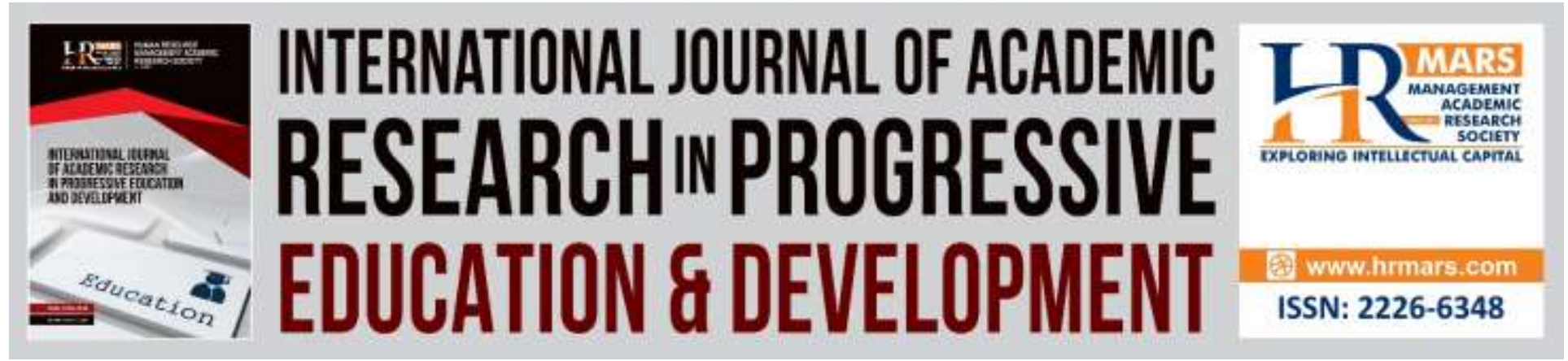

\title{
The Effect of Ownership Structure on Firm Performance among Jordanian Public Shareholders Companies: Board Independence as a Moderating Variable
}

\author{
${ }^{1}$ Mohammad Mustafa Dakhlallh, ${ }^{2}$ Nik Mohd Norfadzilah Nik Mohd \\ Rashid, ${ }^{3}$ Wan Amalina Wan Abdullah, ${ }^{4}$ Abdalrahman Mustafa \\ Dakhlallh \\ 1,2,3 Faculty of Economics and Management Sciences, Universiti Sultan Zainal Abidin, 21300 \\ Kuala Nerus, Terengganu, Malaysia, ${ }^{4}$ Faculty of Management, Al-Hussein Bin Talal University \\ Email: Mohammad_Dakhlallh@yahoo.com
}

\begin{abstract}
The current study aims at providing empirical evidence concerning the relationship between the ownership structure and performance of the shareholding companies listed on the Amman Stock Exchange (ASE). To measure the ownership structure, used institutional and block holders ownership. The performance is measured by using Tobin's Q (TQ). This study also used a moderating variable which is board independence. To achieve the objectives of the study, this study used the panel data method to analyze data for a sample of 180 companies listed on Amman Stock Exchange (ASE) for the period from 2009 to 2017. The findings show that the ownership structure mechanisms have a significant influence on firm performance measure by (TQ). So, institutional ownership shows a significant positive relationship with (TQ), however, the findings show block holders ownership have a significant negative relationship with (TQ). On another hand, the moderating effect of board independence has a significant positive on the relationship between block holders ownership and (TQ) and has a significant negative on the relationship between institutional ownership and (TQ). The findings of this study confirm empirical research continuing to find a new performance measurement to gain a real form of firm performance. Therefore, the evidence of this study provides empirical evidence to stakeholders, managers and interested parties to support them for its decision.

Keyword: Corporate Governance, Ownership Structure, Board Independence, Firm Performance.
\end{abstract}




\section{Introduction}

Corporate governance is a group of a combination of policies, laws, and instructions impacting the way a firm is managed and its control, by protecting the interest stakeholders to avoid conflicting interests (Buallay, Hamdan, \& Zureigat, 2017). Oliver (1995) stated that governance need arises due to the changing nature of the business environment and shareholders are unable to write comprehensive contracts entailing responsibilities, duties, compensation of the controlling group. Fernando (2012) stated that "corporate governance deals with the ways in which suppliers of finance to corporations assure themselves of getting a return on their investment".

As corporate governance is a governing tool that helps stakeholders align their objectives to organizational goals (Stout \& Blair, 2017). One of the issues facing modern organizations is the incompatibility of interests between the principal controlling authority (the board of directors) and the chief executive authority (CEO). The board of directors requires management to conduct wealth maximization practices without taking into account investment risks. On the other hand, the management examines the investment risk and the possibility of default before making any investment projects. This conflict of interest comes at a cost known as agency cost (Husain, Hazoor, \& Sabir, 2014; Hsu \& Wen, 2015; Abedalqader, Abdulmohsen, \& Alssad, 2016; Aguilera, Judge, \& Terjesen, 2018). The conflict of interests between principals and agents in modern corporations has intrigued economists for a long time. To mitigate this problem, classic works in agency theory (Jensen \& Meckling, 1976), propose the use of equity holdings of the firm instead of cash compensation to better align the interests between managers and shareholders. Where agency problem (Conflict of interest between principal and agent) largely depends on ownership structure. Despite the theoretical and practical importance of agency theory, convincing empirical evidence has been elusive and consequently, there is a lack of consensus on whether ownership structure matters for firm performance (Ducassy \& Guyot, 2017).

Recently, the issue of corporate governance and ownership structure (which is a mechanism of corporate governance) has become a highly discussed topic in business and finance due to the balance sheet manipulation and the collapse of public corporations such as Enron and WorldCom. Since these events, corporate governance has undergone various changes (Agyei \& Owusu, 2014). Ownership structure refers to "the relative amount of ownership claims held by insiders (managers) and outsiders" (investors with no direct relationship with the management of the company) (Mccann, 2009). As an ownership structure is considered to be the key in determining the nature of agency theory; that is, whether the dominant conflict is between managers and shareholders, or between majority and minority shareholders (Mang'unyi, 2011).

Countries around the world have started focusing on the development of codes of corporate governance, especially in developing countries. Stakeholders and other interested parties have started to realize the important role of dealing with good practices of corporate governance to eventually protect their interests. Aguilera \& Crespi-Cladera (2016) argue that ownership can be easily compared across countries but corporate governance practices differ significantly across firms' ownership concentration. Moreover, the issue of the effect of ownership structure on firm performance has been a major concern in countries throughout the world. So, Different prior study of corporate governance has tried to investigate the relationship between ownership structure mechanism and the general performance of the firm. Majority of previous studies have 
admitted the firms dealing with better practices of corporate governance must perform better than those having worse practices of corporate governance (Alabdullah, 2018). Nonetheless, a little attention has been given for firm performance in the developing countries especially in Jordan (Alabdullah, Yahya, \& Thurasamy, 2014).

The Jordanian government identified corporate governance system as a requirement for contemporary development and economic growth, its established the first corporate governance code in 2009 (Abed, Al-Attar, \& Suwaidan, 2011; Makhlouf, Hidayah, Laili, Yazis, \& Basah, 2014)to intervene in the case of poor financial performance (Alabdullah et al., 2014), and other forms of mal-management (Al-Zawahreh \& Cox, 2009). However, the Jordanian capital market and its economic situation remain weak, and the World Bank (2014) has shown that the non-financial sector represented by service and industrial companies has experienced a decline in GDP in the last few years. As a result of the regional instability, high level of unemployment, dependency on remittances and grants from Gulf economies beside continued pressure on natural resources. Jordan has faced many internal economic, trade and social challenges as well as the global financial crisis, which calls for the importance of identifying key factors affecting the performance of the company (Alabdullah, 2016). Despite measures taken by regulators, Jordanian companies have not yet reached full compliance with the Corporate Governance Act (Abbadi, Hijazi, \& AlRahahleh, 2016). Due to the fact that developing countries such as Jordan, where corporate governance laws are well documented but not well implemented (Mohammed, 2018). Which required the Amman Stock Exchange (ASE) in 2017 to amend the Corporate Governance Act to become more compliant.

A crucial motivation for examining the emerging economies' corporate governance, such as Jordan, is the significant fluctuations in the number of listed companies on the Amman Stock Exchange in recent times. Where, Jordan is characterized by high ownership concentration, and this clarifies why ownership structure is the predominant mechanism of control in Jordan. Meanwhile, Jordan provides an excellent case to investigate the relationship between ownership structure and firm performance due to the diversity in the ownership structures of Jordanian firms. In addition, the existence proportion of ownership concentration might lead to the CG and weakness in the policies that protect investors' rights in Jordan (Haddad, AlShattarat, AbuGhazaleh, \& Nobanee, 2015).

Therefore, in this context, the current study attempts to provide empirical evidence on the relationship between ownership structure as an important mechanism of corporate governance and firm performance in Jordan, for the period after established the first corporate governance code in 2009. By using panel data over a sample of 180 listed companies on the Amman Stock Exchange (ASE), for the period from 2009 to 2017. So, this study contributes to the existing literature on corporate governance-financial performance relationship in multiple points. Firstly, In the current study, institutional ownership and block holders were used to measure the structure of ownership. Secondly, using market-based measurement (Tobin's Q), to measure firm performance in its relationship with the ownership structure of Jordanian companies. Thirdly, examine the impact of ownership structure on firm performance by using board independence as a moderating variable. 
Vol.8, No. 3, 2019, E-ISSN: 2226-6348 @ 2019 HRMARS

\section{Review of Literature and Hypotheses}

Good corporate governance will protect the shareholders' right, enhancing corporate transparency and ensuring a greater closure of financial and non-financial information (Black, Kim, Jang, \& Park, 2015; Haji, 2014). The investors perceived that a firm with good corporate governance tends to have higher performance and better credibility (Wijethilake, Ekanayake, \& Perera, 2015). The results from many empirical studies are consistent with the argument that well-governed firm has high performance (Black et al., 2015; Ahmed Haji \& Mubaraq, 2015;Kim, Kim, Byun, \& Chun, 2013).

In general, corporate governance components can be divided into three mechanisms which are a board of directors, ownership structure and audit committee. Previous studies investigated the relationship between corporate governance and firm performance and conclude that the ownership structure is one of the most significant factors of corporate governance which affect the firm performance (Rathnayake \& Sun, 2017). This study focuses on the ownership structure as an important internal mechanism. Prior studies have defined the ownership structure as the distribution of shares amongst owners (Gisbert \& Navallas, 2013). In the current study, two mechanisms of ownership structure, namely institutional ownership and block holders, will be investigated with the firm's performance.

\section{Institutional Ownership}

Institutional ownership is an important determinant of firm performance. The Literature argued that the institutional investors seeking to fulfill their fiduciary responsibility require the undertakings concerned to improve the governance of the company and the transparency of their management and to concentrate on the maximization of shareholder value (Soufeljil, Sghaier, Kheireddine, \& Mighri, 2016). Obviously, institutional investors choose a good project to invest their money in looking for more returns and profitability. Furthermore, they play an essential role in corporate governance by imposing greater monitoring of the managers' performance or by taking control of the companies' affair. Subsequently, large investors who have a larger stake in the institution are more interested in monitoring management through representation on the board (Desender, 2009).

Agency theory proposed that institutional investor monitoring can be a significant mechanism of governance. Institutional ownership plays an effective role in monitoring management discretion and enhancing information competence in capital markets, since institutional ownership is sophisticated, with benefits in processing and acquiring information (Ferreira \& Matos, 2008; Koh, 2003). Hence, restraining opportunism and reducing the costs of agency (Al-Najjar, 2010; Chung, Firth, \& Kim, 2002; Shleifer \& Vishny, 1997). In addition, institutional investors play a significant role in reducing external monitoring cost by transferring more information about the company to other shareholders. Moreover, they have much influence on the decisions concerning their large investment in companies (Brickley, Lease, \& Smith, 1988).

Mcconnell \& Servaes (1990) conclude that there is a positive relationship between the presence of institutional investors and the measured performance by the $Q$ of Tobin. Al-Khouri (2006) explored there is a positive and significant relationship between institutional ownership and firm value for 89 industrial and service firms listed at the Amman Stock Exchange (ASE) over 
the period 1998-2001. Based on a sample of 134 firms listed on the KSE, the result showed a positive relationship between institutional investors and KSE firm performance, suggesting the powerful and influential role that institutional investors play as a corporate governance mechanism (Alfaraih, Alanezi, \& Almujamed, 2012). As Arouri, Hossain, \& Muttakin (2014) provided evidence that institutional ownership has a positive impact on the performance of 58 banks operating in the GCC markets. Soufeljil et al., (2016) also found there is a positive influence for institutional ownership on the performance of the firm. The study of a sample of Chinese companies listed from 2004 to 2014. The results showed that institutional ownership positively affects the performance of the company (Lin \& Fu, 2017). Conversely, Ferreira and Matos (2008) found a significantly negative relationship between institutional ownership and Tobin's $Q$, using a comprehensive database of equity holdings in 27 countries during the 2000-2005 period. The study by Khamis, Elali, \& Hamdan (2015) explores a negative relationship between institutional ownership and the performance of a company the presence of Tobin's Q to measure it. As Arora \& Sharma (2016) also found the presence of significant as well as a negative correlation between the performance of a firm and the institutional ownership. Therefore, according to agency theory, the following hypothesis was developed:

$H 1$. There is a positive relationship associated with institutional ownership and firm performance.

\section{Block holders Ownership}

Ownership concentration refers to the percentage of shares held by the largest block holders (Claessens, Djankov, Fan, \& Lang, 2002). Considered ownership concentrated when a small number of shareholders own a significant proportion of shares issued by the company (Sheikh, Wang, \& Khan, 2013). A large shareholder is defined as a shareholder holding (directly or indirectly) at least $5 \%$ of the total number of all the voting shares in the firm (Amran \& Che Ahmad, 2014). More dispersed ownership means higher agency costs (Jensen and Meckling, 1976). Furthermore, concentrated ownership is considered one of the governance techniques that hinder firm management from deviating from shareholder interests, as large block holders have the tendency to monitor managers, more than small shareholders (Levine, 2004). Thus, the block holders are probably to be more effective in monitoring management than small shareholder (Al-Thuneibat, 2018). Where, Gillan \& Starks (2003) indicated that when ownership is concentrated, the agency conflict among managers and shareholders is minimized. Resulting in more efficient governance for the benefit of all shareholders.

Although different empirical evidence for an effect of block holders on the performance of the firm's, prior empirical studies have recognized this importance. In particular, block holders play an important role in corporate governance because they have relevant skills, time and attention to a firm's performance. Some of previous studies have reported a positive relationship between ownership concentration and corporate performance, as previous empirical studies found that ownership concentration may constrain managerial diversion from shareholder interests and enhance the power of shareholders against the power of managers and therefore the value of the firm and its profitability (Perrini, Rossi, \& Rovetta, 2008; Sheikh et al., 2013;Khamis et al., 2015; Saleh, Halili, Zeitun, \& Salim, 2017). Ullah, Ali, \& Mehmood (2017) confirm a significant positive role of outside block holders in affecting firm performance. In the Jordanian context, found that the ownership of Jordanian companies is characterized by a high 
degree of concentration, which is expected to play an important role in governing the corporate activities and this will be reflected on the performance of the corporation (A.- Haddad, Jamil, \& Sufy, 2011). Jaafar \& El-Shawa (2009)examined the influence of ownership concentration on performance in Jordan and found that the ownership concentration, has a significant and positive relationship with performance.

On the other hand, Barroso, Ali, \& Lesage (2016) found that there is no significant relationship between concentrated ownership and company value. Meanwhile, block holders ownership itself has no significant impact on firm performance (Hoang, Nguyen, \& Hu, 2017). AlThuneibat (2018) found also the results of the effect of the concentrated ownership on the performance of the Jordanian firm's measured by ROA is positive but insignificant. However, previous studies argued that dispersed ownership is most common in developed countries and concentrated ownership is most common in developing countries (Al-Thuneibat, 2018).

Conversely, (Cronqvist \& Nilsson, 2003) found a non-linear relationship between ownership concentration and firm performance or negative impact. They found that the greater dispersion of ownership the higher is valuation ratio, profit margin, and growth rate of net assets, depending upon control type. (Fazlzadeh, 2011) argued that internal stakeholders (managers and employees) will be discouraged from costly investing and major shareholders will have the incentives to use their control to obtain their specific interests. As (Mohammed, 2018) found that block holders are negatively and significantly associated with the performance of the Jordanian firms. Therefore, the negative aspects of this issue, as claimed by agency theory, are majority shareholders may consider their interests at the expense of minorities (Cheung \& Chan, 2004). Finally, according to the above and agency theory, the following hypothesis was developed:

H2. There is a positive relationship associated with block holders ownership and firm performance.

\section{Moderating Effect of the Board Independence}

The management scholars posit that the board's impact on firm performance depends on both the incentives and the abilities of board members, and the choices a firm faces regarding the costs and benefits of different board structures (Duru, lyengar, \& Zampelli, 2016). Although information acquisition and processing costs are likely to be higher for more independent boards (Duru et al., 2016). But, extant empirical evidence of firm transparency improves with increases in board independence, thus reducing information costs within the firm (Armstrong, Core, \& Guay, 2014).Agency theory argues that a larger proportion of independent directors will promote better firm performance. This theory assumes that managers are individualistic, opportunistic and self-serving. Then, effective monitoring by independent boards is key to making executives effectively pursue shareholder rather than self-interests. Consequently, boards with more independent directors can perform managerial monitoring tasks more effectively (Fama \& Jensen, 1983; Jensen and Meckling, 1976). On the other hand, stewardship theory argues that boards dominated by insiders are to be preferred to boards dominated by outsiders as managers are assumed to be collectivistic ally and reorganization oriented, as well as trustworthy.

According to Nguyen, Locke, \& Reddy (2014), board diversity has a positive impact on firm performance due to better monitoring and control, more independent and lead to higher firm performance. Kim et al., (2013) reveal in their study that independent directors are less 
dependent on management and more concern in protecting their reputation in the market and thus may function better than non-independent directors may. (Balsmeier, Buchwald, \& Stiebale, 2014) found in their studies that independent directors with an appropriate professional background can provide valuable knowledge and expertise to the firm. Wu \& Li (2015); Al-Najjar (2014) point out that independent directors provide better and effective monitoring and control thus increase the overall firm performance. In the Jordanian context, a study undertaken by AlHawary (2011) found that the board independent had a significant and positive effect on a firm's performance. As Alabdullah, Yahya, Nor, \& Majeed (2016) found a positive relationship and significant between the independence of the board with a financial firm's performance. Using a sample of 105 listed companies in the financial sector on Amman Stock Exchange market over the period 2011 to 2013, Zayed (2017), found that a positive relation and significant between board independence with financial firm performance.

On another hand, some of the previous studies supported those independent directors negatively influence firm performance. Sheikh et al., (2013) support the negative relationship between independent directors and Pakistani's firm performance. While Bhuiyan (2015) support firm with a higher number of independent directors have worse performance because they cannot devote sufficient time to monitor the firm due to too many boards to serve. As a result, the advising capabilities and monitoring are reduced and affect firm performance. Balsmeier et al., (2014) argue that independent directors might more concern about their private benefits than the performance of the firm they are supposed to monitor and advise. Using a sample of firms traded on the Athens Stock Exchange during 2008-2012. Zhou, Owusu-Ansah, \& Maggina (2018) they found that firms had to have more independent directors on their boards are associated with poor performance. Contrarily, Nguyen et al., (2014) found the board composition has no impact on firm performance due to independent directors may have a lack of knowledge about the firm and industry.

Finally, Schwartz-Ziv \& Weisbach (2013), using private data on detailed minutes of board meetings, suggest that boards spend most of their time monitoring management. Jensen (1993) show that independent directors enhance the monitoring role of the board. Even regulators consider board independence to be the key attribute of a board with high monitoring ability (Adams, Hermalin, \& Weisbach, 2010). Accordingly, we argue that the combination of an ownership structure and an independent board will result in greater firm performance. Therefore, according to the explanation above and the agency theory as well as stewardship theory, this research has developed the following hypothesis:

H3: There is a Moderating Effect of board independence on the Relationship Between ownership structure and Firm Performance.

\section{Research Methodology}

\section{Study Population Sample and Resources of Data}

The present study investigates the link between corporate governance represented by ownership structure and firm performance expressed by Tobin's $Q$ in Jordan. The study focused on companies listed on the Amman Stock Exchange (ASE) as it is one of the largest stock exchanges in the Middle East, in addition, its strategic and vital location among the countries of the region and because it is an economic channel to large markets. Therefore, the current study population 
includes the public shareholder companies listed on the Amman Stock Exchange (ASE), excluding banks sector, for the period from 2009 to 2017. The reason behind excluding banks sector referred to the highly regulated environment applicable to banks sector. As well, the reason behind choosing the study period from 2009 to 2017 was referred to is start work on the reforms of the Corporate Governance Guide in Jordan in September 2009. Furthermore, as disclosed by Alabdullah (2016) and the indicators by the World Bank (2016) that the Jordanian companies specifically the industry and service sectors faced a reduction in GDP in the last ten years. In addition, the data in this period is available to serve the objective of this study.

The setting of the data of this study comprises financial and non-financial information for the companies listed on ASE through the period 2009-2017, collected from the annual reports published on ASE website and of DataStream site. Where, used the quantitative method to achieve the study objective, and used secondary data to data collected to saves time and costs of acquiring information, and provide a lot of information for research and problem solving (Uma \& Roger, 2003). So, the study sample consisted of 180 companies from the financial, industrial and service companies for 1620 firm-years, has been summarized in Table 1.

Table 1. Sample Selection

\begin{tabular}{ll}
\hline Sector & Total firm-size \\
\hline Financial sector & 86 \\
Service sector & 45 \\
Industrial sector & 49 \\
Total firm-year in the final sample & $\mathbf{1 8 0}$ \\
\hline
\end{tabular}

\section{Measurement of Variables}

The aim of this study at investigating the influence of ownership structure on the firm's performance, to analyze the performance of the firm, this study used Tobin's $Q$ as a measure of the dependent variable. TQ (Tobin, 1969) is a combination of different accounting as well as market values via considering the value of the market of a firm. Tobin's $Q$, as a result, is a powerful tool to utilize, since it analyses corporate performance from a market perspective, a marketbased measurement which is categorized as long term, and therefore reflects the present value of future cash flows based on current and future information (Wahla, Shah and Hussain, 2012). So, this study measures firm performance (dependent variable) through Tobin's $Q$ its relationship with the ownership structure which are: the institutional ownership (IO) and block holders ownership (BHO) as independent variables. In addition, Moderate variable includes the board of director's independence (BI). Table 2 shows a summary of variables measurement. 
INTERNATIONAL JOURNAL OF ACADEMIC RESEARCH IN PROGRESSIVE EDUCATION AND DEVELOPMENT

Vol.8, No. 3, 2019, E-ISSN: 2226-6348 @ 2019 HRMARS

Table 2. Description of Measurements of the Variables and Literature

\begin{tabular}{|c|c|c|c|}
\hline Variables & $\begin{array}{c}\text { Symbo } \\
1\end{array}$ & Measurement & $\begin{array}{c}\text { Source of } \\
\text { Information }\end{array}$ \\
\hline \multicolumn{4}{|l|}{ Dependent Variable: } \\
\hline $\begin{array}{l}\text { Firm performance } \\
\text { (Tobin's Q) }\end{array}$ & TQ & $\begin{array}{l}\text { (The ratio of the book value of total assets }- \text { (the } \\
\text { book value of total equity }+ \text { the market value of } \\
\text { total equity)) / the book value of total assets. }\end{array}$ & $\begin{array}{l}\text { Thompson Data } \\
\text { Stream }\end{array}$ \\
\hline \multicolumn{4}{|l|}{ Independent variable: } \\
\hline Institutional Ownership & $\mathrm{IO}$ & $\begin{array}{l}\text { The percentage of shares owned by Institutions } \\
\text { and other companies to the total number of shares } \\
\text { issued. }\end{array}$ & Annual Report \\
\hline Block holders Ownership & $\mathrm{BHO}$ & $\begin{array}{l}\text { The percentage of shares owned by block holders } \\
\text { is } 5 \% \text { or greater to the total number of shares } \\
\text { issued. }\end{array}$ & Annual Report \\
\hline $\begin{array}{l}\text { Moderating Variable: } \\
\text { Board independence }\end{array}$ & BI & $\begin{array}{l}\text { The percentage of independent non-executive } \\
\text { directors on the board of directors. }\end{array}$ & Annual Report \\
\hline
\end{tabular}

\section{Model Specification}

In order to test the study hypotheses, the model was used to depicts the relationship between performance measured by Tobin's $Q$ and institutional (IO) ownership and block holders ownership (BHO), and the effect of moderate variable of the board independence (BI). The variables used in this study in the sample, their definition and measurement are shown in Table 2. Based on the table above, the model of this study is defined by the following equation:

$$
\mathrm{TQ}=\alpha+\beta_{1} \mathrm{IO}+\beta_{2} \mathrm{BHO}+\beta_{3} \mathrm{BI}+\varepsilon
$$

Particularly, this research comprised of public shareholder companies listed on the Amman Stock Exchange from 2009 to 2017. Therefore, the samples were collected based on the availability of the companies which had already been listed during the period of the investigation. Meanwhile, the second criterion that was considered for sample selection was the availability of the selected companies' financial data required for the analyses in this study. Furthermore, the selection of the samples was based on the list of companies provided by the Amman Stock Exchange. Therefore, the database of Thompson Data Stream was used in order to retrieve the data from the selected companies. Thus, the final sample that was gathered for this particular study comprised of 180 public listed companies on the Amman Stock Exchange. Hence, from these samples, the total firm years of companies tested in this particular study was 1620 .

The researcher used panel data methodology to analyze data across firms and over the years. Panel data sets better identify the estimate effects that are not detectable in pure cross-sectional or pure time series analysis (Ahmed Sheikh \& Wang, 2012). The regression has been carried out for a complete set of data to understand the differential impact of ownership structure downloaded by some variables on various types of companies (Mishra \& Kapil, 2017). For the data analyses, the study employed the Fixed Effect regression method in order to investigate the association between selected components with the changes in the firm performance in the business organization. 
INTERNATIONAL JOURNAL OF ACADEMIC RESEARCH IN PROGRESSIVE EDUCATION AND DEVELOPMENT

Vol.8, No. 3, 2019, E-ISSN: 2226-6348 @ 2019 HRMARS

\section{Empirical Results and Discussions \\ Descriptive Statistics}

Table 3 presents some descriptive statistics for the study variables of 180 Jordanian companies and 1620 firm-year observations listed on ASE during the period (2009-2017). This table shows the means and standard deviations of the dependent and independent variables included in the regression model.

Table 3.Descriptive Statistics.

\begin{tabular}{lcccc}
\hline & TQ & IO & BHO & BI \\
\hline Mean & 0.998948 & 0.308220 & 0.621214 & 0.423966 \\
Median & 0.998954 & 0.306255 & 0.619272 & 0.432941 \\
Maximum & 0.999288 & 0.375917 & 0.902719 & 0.456683 \\
Minimum & 0.998090 & 0.000000 & 0.497940 & 0.000000 \\
Std. Dev. & $8.09 \mathrm{E}-05$ & 0.036975 & 0.048097 & 0.040763 \\
Skewness & -3.159501 & -4.092431 & 0.790212 & -7.108561 \\
Kurtosis & 35.08297 & 32.53694 & 9.354116 & 63.52163 \\
Jarque-Bera & 72174.15 & 63411.03 & 2893.895 & 260887.1 \\
Probability & 0.000000 & 0.000000 & 0.000000 & 0.000000 \\
\hline
\end{tabular}

Table 3 explains the descriptive statistics for the variables of the study, for the 180 public shareholders companies listed on Amman Stock Exchange (ASE) by using descriptive statistics represented by mean, standard deviation, minimum and maximum. Table 3. presents the distribution of all variables in this study. Based on the results of descriptive statistics, the dependent variable which is Tobin's Q showed that the mean Tobin's Q of Jordanian companies is $0.998948 \%$ with ranges between $0.998090 \%$ and $0.999288 \%$, with a standard deviation level of Tobin's $Q$ equal to $8.09 \mathrm{E}-05$. Furthermore, the table shows that the mean of institutional ownership (IO) is $0.308220 \%$ with a standard deviation of $0.036975 \%$, the minimum is $0.000 \%$ with a maximum level of Tobin's $Q$ equal to $0.375917 \%$. While the mean of block holders ownership (BHO) is $0.621214 \%$ with a standard deviation of $0.048097 \%$, the minimum is $0.497940 \%$ with a maximum level of Tobin's Q equal to $0.902719 \%$. As a result of that, the mean of the block holders ownership (BHO) represents the higher than mean institutional ownership (IO). This means that block holders ownership (BHO) is largely concentrated in Jordanian companies at $5 \%$ or greater. In addition, the current study resorts to the used a moderating variable is board independence (BI), to show its influence on the relation between ownership structure and firm performance (Tobin's Q). The table shows that board independence (BI) ranges between 0.000 and $0.456683 \%$ with a mean of $0.423966 \%$ with a standard deviation of $0.040763 \%$. This means that the independence of the Board of Directors has not yet reached the level stipulated by the corporate governance of Jordanian companies, which is two-thirds of the Board of Directors. 
INTERNATIONAL JOURNAL OF ACADEMIC RESEARCH IN PROGRESSIVE EDUCATION AND DEVELOPMENT

Vol.8, No. 3, 2019, E-ISSN: 2226-6348 @ 2019 HRMARS

Multiple Regression Analysis

Table 4. Regression Analysis Using Tobin's Q

\begin{tabular}{lllll}
\hline Variable & Coefficient & Std. Error & t-Statistic & Prob. \\
\hline IO & 0.000862 & 0.000178 & 4.854869 & 0.0000 \\
BHO & -0.000970 & $7.97 \mathrm{E}-05$ & -12.17395 & 0.0000 \\
IOBI & -0.001169 & 0.000553 & -2.115974 & 0.0345 \\
BHOBI & 0.003155 & 0.000171 & 18.46783 & 0.0000 \\
C & 0.998611 & $8.27 \mathrm{E}-05$ & 12076.95 & 0.0000 \\
R-squared & 0.560807 & Mean dependent var & 0.998949 \\
Adjusted R-squared & 0.555813 & S.D. dependent var & $8.09 \mathrm{E}-05$ \\
S.E. of regression & $1.70 \mathrm{E}-05$ & Akaike info criterion & -19.01920 \\
Sum squared resid & $4.15 \mathrm{E}-07$ & Schwarz criterion & -18.40698 \\
Log-likelihood & 15589.55 & Hannan-Quinn criteria. & -18.79200 \\
F-statistic & 192.3690 & Durbin-Watson stat & 2.227825 \\
Prob(F-statistic) & 0.000000 & & \\
\hline
\end{tabular}

The regression of the relationship between ownership structure and firm performance are presented in Table 4 above. This study tested three hypotheses. Model of the study shows presents the market-based performance, Tobin's Q. For the analysis conducted in on above, the model produces R2 of 0.560807 , F-value is 192.3690, and P-value is 0.000 and highly significant at level 5\%. The adjusted R2 indicates that 0.555813 in Table 3 above the firm performance can be explained by the overall explanatory variables in this study.

Based on Table 4 above, the results were depicted as there is a significant relationship between all the selected components towards the changes in the firm performance in the business organization. These results were explained below: the regression result in Model on above, indicates that institutional ownership (IO) is positively and significantly associated with the firm performance measured by (TQ), $(\beta=0.000862 ; t=4.854869 ; P=0.000)$. The positive relationship reference, when the percentage of institutional ownership rises, will be reflected positively on the value of the firm, leading to the increasing performance of the firm. The result is consistent with the hypothesis that supports positive institutional ownership relation with the firm performance (TQ), hence $\mathrm{H} 1$ is accepted. The result of this study agrees with the prior studies results done by Arouri et al., 2014;Soufeljil et al., 2016; Lin \& Fu, 2017. And disagree with the previous studies as Ferreira \& Matos, 2008;Khamis et al., 2015;Arora \& Sharma, 2016. Agency theory proposed that institutional investor monitoring can be a significant mechanism of governance. Where institutional investors have a significant function in reducing external controlling cost by transferring information to other shareholders about the firm. So, the result of the current study is consistent with the agency theory about important institutional ownership role in increase firm performance.

While, the finding reveals that found that block holders ownership (BHO) has negative and significant relationship at $1 \%$ level with the firm performance (TQ), $(\beta=-0.000970 ; t=-12.17395$; $p=0.000)$. Thus, the result is not consistent with the hypothesis that supports a positive 
relationship with firm performance. Therefore, $\mathrm{H} 2$ is rejected. A negative result means, when the percentage of block holders ownership is increasing, lead that to reduced firm performance. These findings agree with the previous study such as Jaafar \& El-Shawa, 2009; A.- Haddad et al., 2011; Ullah et al., 2017. And disagree with the study by Fazlzadeh, 2011; Mohammed, 2018. A negative result means, when there is a high concentrate of the block holders, they will have the incentives to use their control to achieve their own interests, thereby reducing the performance of the firm. Therefore, this finding is not consistent with agency theory which supports that block holders ownership leads to reduce agency costs, which leads to better performance.

The current study provides evidence that board independence (BI) has significant on the relationship between ownership structure and firm performance. The model on above, explains that board independence $(\mathrm{BI})$ has significant negative on the relationship institutional ownership with the firm performance (TQ), $(\beta=-0.001169 ; t=-2.115974 ; p=0.0345)$. Which suggests that the increase of board independence, it could decrease the relationship between institutional ownership and firm performance. Agency theory assumes that a larger proportion of independent directors will leads to perform better. While stewardship theory discusses that board dominated by insiders (not independent) are better than to independent board of directors to achieve performance well. Therefore, the result of the current study not consistent with the agency theory, and agree with the stewardship theory. As The model on above, explains that board independence (BI) has significant positive on the relation block holders ownership with the firm performance (TQ), $(\beta=0.003155 ; t=18.46783 ; p=0.000)$. Which suggests that the increase of board independence (BI), it could increase the relationship between institutional ownership and firm performance. Jensen and Meckling (1976) assume more independent board of directors can perform managerial monitoring tasks more effectively to improve the performance. But, stewardship theory prefers that boards not independent is better to improve performance, as well as they are trustworthy. Therefore, the result of the current study consistent with the agency theory, and not consistent with the stewardship theory. Finally, the result of the present study shows a significant relationship with the $\mathrm{H} 3$, thus accepting $\mathrm{H} 3$.

\section{Conclusion}

The objective of this study is to investigate the effect of ownership structure (institutional and block holders ownership) as one of the important corporate governance mechanisms on firm performance and investigate moderating effect of board independence on that relation, for Jordanian companies listed on Amman Stock Exchange (ASE). This study comprised of selected public listed companies on the Amman Stock Exchange from 2009 to 2017. Therefore, the samples were collected based on the availability of the companies which had already been listed during the period of the investigation and financial data required for the analyses in this study for the selected companies. Thus, by using the panel data method, the final sample that was gathered for this particular study comprised of 180 public listed companies on the Amman Stock Exchange for 1620 firm years.

Based on the findings above, it is found that institutional ownership is a positive and significant relationship with the performance of the firm measured by (TQ). While it is found that block holders ownership is negatively and significantly associated with the firm performance measured by (TQ). On another hand, it is found the moderating effect of board independence 
has a significant negative on the relationship between institutional ownership with firm performance measured by (TQ). On the contrary, found the moderating effect of board independence has significant positive on the relationship between block holders ownership with firm performance measured by (TQ). Thus, the moderating effect of board independence on the relationship between block holders ownership with firm performance measured by (TQ) is significant.

Finally, the suggestion for future researches in both developed and developing may include more investigate the relationship between variables of ownership structure and firm performance, to identify the results from a different perspective and from different levels. In addition, examining other variables of ownership structure such as internal managers ownership and foreign ownership. Also examining the moderating or mediating influence of other variables on the relation between chosen variables and firm performance, such as audit committee mechanisms. Future researchers can also use different performance measure, such as ROA, ROE, market share. Future researches also may include examining long periods before and after reform corporate governance in Jordan.

\section{References}

Abbadi, S., Hijazi, Q., \& Al-Rahahleh, A. (2016). Corporate Governance Quality and Earnings Management: Evidence from Jordan. Australasian Accounting, Business and Finance Journal, 10(2), 54-75. https://doi.org/10.14453/aabfj.v10i2.4

Abed, S., Al-Attar, A., \& Suwaidan, M. (2011). Corporate Governance and Earnings Management: Jordanian Evidence. International Business Research, 5(1), 216-225. https://doi.org/10.5539/ibr.v5n1p216

Abedalqader, A., Abdulmohsen, A. T. H., \& Alssad, A. A. S. A. (2016). The effect of corporate governance mechanisms on earnings management: evidence from Saudi Arabia. Review of International Business and Strategy, 26(1). https://doi.org/http://dx.doi.org/10.1108/RIBS10-2013-0100

Adams, R. B., Hermalin, B. E., \& Weisbach, M. S. (2010). The role of boards of directors in corporate governance: A conceptual framework and survey. Journal of Economic Literature, 48(1), 58-107.

Aguilera, R. V., \& Crespi-Cladera, R. (2016). Global corporate governance: On the relevance of firms' ownership structure. Journal of World Business, 51(1), 50-57. https://doi.org/10.1016/j.jwb.2015.10.003

Aguilera, R. V., Judge, W. Q., \& Terjesen, S. A. (2018). Corporate governance deviance. Academy of Management Review, 43(1), 87-109. https://doi.org/10.5465/amr.2014.0394

Agyei, A., \& Owusu, A. R. (2014). The effect of ownership structure and corporate governance on capital structure of Ghanaian listed manufacturing companies. International Journal of Academic Research in Accounting, Finance and Management Sciences, 4(1), 109-118.

Haji, A. (2014). The relationship between corporate governance attributes and firm performance before and after the revised code: Some Malaysian evidence. International Journal of Commerce and Management, 24(2), 134-151. https://doi.org/10.1108/IJCoMA-02-20120009

Haji, A., \& Mubaraq, S. (2015). The implications of the revised code of corporate governance on 
firm performance: A longitudinal examination of Malaysian listed companies. Journal of Accounting in Emerging Economies, 5(3), 350-380.

Sheikh, A. N., \& Wang, Z. (2012). Effects of corporate governance on capital structure: empirical evidence from Pakistan. Corporate Governance: The International Journal of Business in Society, 12(5), 629-641.

Al-Hawary, S. (2011). The effect of banks governance on banking performance of the Jordanian commercial banks: Tobin's Q model'An applied study'. International Research Journal of Finance and Economics, 71(5), 34-47.

Al-Khouri, R. (2006). Corporate governance and firms value in emerging markets: The case of Jordan. Journal of Transnational Management, 12(1), 25-49.

Al-Najjar, B. (2010). Corporate governance and institutional ownership: evidence from Jordan. Corporate Governance: The International Journal of Business in Society, 10(2), 176-190.

Al-Najjar, B. (2014). Corporate governance, tourism growth and firm performance: Evidence from publicly listed tourism firms in five Middle Eastern countries. Tourism Management, 42, 342-351. https://doi.org/10.1016/j.tourman.2013.09.008

Al-Thuneibat, A. (2018). The Relationship between the Ownership Structure, Capital Structure and Performance. JABM JOURNAL of ACCOUNTING-BUSINESS \& MANAGEMENT, 1(25), 120.

Al-Zawahreh, A. A. S., \& Cox, M. A. A. (2009). The practice of operations research in Jordanian industry: a field study. International Journal of Information and Operations Managem Educ, 3(2), 178.

Alabdullah, T. T. Y. (2016). Are Board Size And Ownership Structure Beneficial In Emerging Markets' Firms? Evidence From Jordan. International Journal of Management \& Information Systems (IJMIS), 20(3), 87. https://doi.org/10.19030/ijmis.v20i3.9752

Alabdullah, T. T. Y. (2018). The relationship between ownership structure and firm financial performance: Evidence from Jordan. Benchmarking, 25(1), 319-333. https://doi.org/10.1108/BIJ-04-2016-0051

Alabdullah, T. T. Y., Yahya, S., Nor, M. I., \& Majeed, F. Q. (2016). An investigation of corporate governance from a new perspective: Examining the financial performance of companies and the impact of executive turnover. Corporate Board: Role, Duties and Composition, 12(1), 5369.

Alabdullah, T. T. Y., Yahya, S., \& Thurasamy, R. (2014). Corporate governance development: New or old concept ? European Journal of Business and Managemen, 6(7), 312-315.

Alfaraih, M., Alanezi, F., \& Almujamed, H. (2012). The Influence of Institutional and Government Ownership on Firm Performance: Evidence from Kuwait, 5(10), 192-200. https://doi.org/10.5539/ibr.v5n10p192

Amran, N. A., \& Che Ahmad, A. (2014). Effects of Ownership Structure on Malaysian Companies Performance. Asian Journal of Accounting and Governance, 4(1), 51-60. https://doi.org/10.17576/ajag-2013-4-5774

Armstrong, C. S., Core, J. E., \& Guay, W. R. (2014). Do Independent Directors Cause Improvements in Firm Transparency? Do Independent Directors Cause Improvements in Firm Transparency? $113,383-403$.

Arora, A., \& Sharma, C. (2016). Corporate governance and firm performance in developing 
INTERNATIONAL JOURNAL OF ACADEMIC RESEARCH IN PROGRESSIVE EDUCATION AND DEVELOPMENT

Vol.8, No. 3, 2019, E-ISSN: 2226-6348@ @ 2019 HRMARS

countries: evidence from India. Corporate Governance (Bingley), 16(2), 420-436. https://doi.org/10.1108/CG-01-2016-0018

Arouri, H., Hossain, M., \& Badrul Muttakin, M. (2014). Effects of board and ownership structure on corporate performance: Evidence from GCC countries. Journal of Accounting in Emerging Economies, 4(1), 117-130. https://doi.org/10.1108/JAEE-02-2012-0007

Balsmeier, B., Buchwald, A., \& Stiebale, J. (2014). Outside directors on the board and innovative firm performance. Research Policy, 43(10), 1800-1815.

Barroso, R., Ali, C. Ben, \& Lesage, C. (2016). Blockholders ' Ownership and Audit Fees : The Impact of the Corporate Governance Model Blockholders ' Ownership and Audit Fees: The Impact of the Corporate Governance, 8180 (October). https://doi.org/10.1080/09638180.2016.1243483

Bhuiyan, M. B. U. (2015). Do problem directors affect firm operating performance? Asian Review of Accounting, 23(2), 170-185.

Black, B. S., Kim, W., Jang, H., \& Park, K. S. (2015). How corporate governance affect firm value? Evidence on a self-dealing channel from a natural experiment in Korea. Journal of Banking and Finance (Vol. 51). https://doi.org/10.1016/j.jbankfin.2014.08.020

Brickley, J. A., Lease, R. C., \& Smith, C. W. (1988). Ownership structure and voting on antitakeover amendments. Journal of Financial Economics, 20(C), 267-291. https://doi.org/10.1016/0304-405X(88)90047-5

Buallay, A., Hamdan, A., \& Zureigat, Q. (2017). Corporate Governance and Firm Performance: Evidence from Saudi Arabia. Australasian Accounting, Business and Finance Journal, 11(1), 78-98. https://doi.org/10.14453/aabfj.v11i1.6

Cheung, S. Y. L., \& Chan, B. Y. (2004). Corporate Governance in Asia, 11(2), 1-31.

Chung, R., Firth, M., \& Kim, J.-B. (2002). Institutional monitoring and opportunistic earnings management. Journal of Corporate Finance, 8(1), 29-48.

Claessens, S., Djankov, S., Fan, J. P. H., \& Lang, L. H. P. (2002). Disentangling the incentive and entrenchment effects of large shareholdings. The Journal of Finance, 57(6), 2741-2771.

Cronqvist, H., \& Nilsson, M. (2003). Agency costs of controlling minority shareholders. Journal of Financial and Quantitative Analysis, 38(4), 695-719.

Desender, K. A. (2009). The relationship between the ownership structure and board effectiveness. University of Illinois at Urbana-Champaign, College of Business Working Papers, 9-105.

Ducassy, I., \& Guyot, A. (2017). Complex ownership structures, corporate governance and firm performance: The French context. Research in International Business and Finance, 39, 291306. https://doi.org/10.1016/j.ribaf.2016.07.019

Duru, A., lyengar, R. J., \& Zampelli, E. M. (2016). The dynamic relationship between CEO duality and firm performance: The moderating role of board independence. Journal of Business Research, 69(10), 4269-4277. https://doi.org/10.1016/j.jbusres.2016.04.001

Fama, E. F., \& Jensen, M. C. (1983). Separation of ownership and control. The Journal of Law and Economics, 26(2), 301-325.

Fazlzadeh, A. (2011). The Examination of the Effect of Ownership Structure on Firm Performance in Listed Firms of Tehran Stock Exchange Based on the Type of the Industry, 6(3), 249-266.

Fernando, A. C. (2012). Corporate Governance: Principles, Polices and Practices, 2/e. Pearson 
INTERNATIONAL JOURNAL OF ACADEMIC RESEARCH IN PROGRESSIVE EDUCATION AND DEVELOPMENT

Vol.8, No. 3, 2019, E-ISSN: 2226-6348 @ 2019 HRMARS

Education India.

Ferreira, M. A., \& Matos, P. (2008). The colors of investors' money: The role of institutional investors around the world. Journal of Financial Economics, 88(3), 499-533.

Gillan, S., \& Starks, L. T. (2003). Corporate governance, corporate ownership, and the role of institutional investors: A global perspective. Journal of Applied Finance, 13(2).

Gisbert, A., \& Navallas, B. (2013). The association between voluntary disclosure and corporate governance in the presence of severe agency conflicts. Advances in Accounting, 29(2), 286298. https://doi.org/10.1016/j.adiac.2013.07.001

Haddad, A.--, Jamil, F., \& Sufy, A. (2011). The Effect of Corporate Governance on the Performance of Jordanian Industrial Companies: An empirical study on Amman Stock Exchange. International Journal of Humanities and Social Science, 1(4), 55-69.

Haddad, A. E., AlShattarat, W. K., AbuGhazaleh, N. M., \& Nobanee, H. (2015). The impact of ownership structure and family board domination on voluntary disclosure for Jordanian listed companies. Eurasian Business Review (Vol. 5). Springer International Publishing. https://doi.org/10.1007/s40821-015-0021-5

Hoang, L. T., Nguyen, C. C., \& Hu, B. (2017). Ownership Structure and Firm Performance Improvement: Does it Matter in the Vietnamese Stock Market?, 1-13. https://doi.org/10.1111/1759-3441.12185

Hsu, M. F., \& Wen, S. Y. (2015). The Influence of Corporate Governance in Chinese Companies on Discretionary Accruals and Real Earnings Management. Asian Economic and Financial Review, 5(3), 391-406. https://doi.org/10.18488/journal.aefr/2015.5.3/102.3.391.406

Husain, S., Hazoor, T., \& Sabir, M. (2014). Impact of Family Ownership on Market Value of a Firm : a Comparative Analysis of Family and Non-Family Companies Listed At Karachi Stock Exchange (Pakistan ), 3(12), 673-683.

Jaafar, A., \& El-Shawa, M. (2009). Ownership concentration, board characteristics and performance: evidence from Jordan. In Accounting in Emerging Economies (pp. 73-95). Emerald Group Publishing Limited.

Jensen, M. C., W. H. M. (1976). Theory of the Firm : Managerial Behavior, Agency Costs and Ownership Structure Theory of the Firm : Managerial Behavior, Agency Costs and Ownership Structure. Journal of Financial Economics, 3(4), 305-360.

https://doi.org/http://dx.doi.org/10.1016/0304-405X(76)90026-X

Jensen, M. C. (1993). The modern industrial revolution, exit, and the failure of internal control systems. The Journal of Finance, 48(3), 831-880.

Khamis, R., Elali, W., \& Hamdan, A. (2015). Ownership structure and corporate financial performance in Bahrain bourse. Corporate Ownership and Control, 13(1), 413-434.

Kim, D. H., Kim, J., Byun, Y., \& Chun, S. H. (2013). A Study on the Effect of Governance Adequacy on the Corporate Performance. Procedia - Social and Behavioral Sciences, 107, 59-66. https://doi.org/10.1016/j.sbspro.2013.12.399

Koh, P. S. (2003). On the association between institutional ownership and aggressive corporate earnings management in Australia. The British Accounting Review, 35(2), 105-128.

Levine, R. (2004). The corporate governance of banks: A concise discussion of concepts and evidence. The World Bank.

Lin, Y. R., \& Fu, X. M. (2017). Does institutional ownership influence firm performance? Evidence 
INTERNATIONAL JOURNAL OF ACADEMIC RESEARCH IN PROGRESSIVE EDUCATION AND DEVELOPMENT

Vol.8, No. 3, 2019, E-ISSN: 2226-6348 @ 2019 HRMARS

from China. International Review of Economics and Finance, 49(October 2016), 17-57. https://doi.org/10.1016/j.iref.2017.01.021

Makhlouf, M. H., Hidayah, N., Laili, B., Yazis, M., \& Basah, A. (2014). Board of Directors Characteristics and Firms Performance among Jordanian Firms, Proposing Conceptual Framework, 1(1), 18-23.

Mang'unyi, E. E. (2011). Ownership Structure and Corporate Governance and Its Effects on Performance: A Case of Selected Banks in Kenya. International Journal of Business Administration, 2(3), 2-18. https://doi.org/10.5430/ijba.v2n3p2

Mccann, B. T. (2009). Working Paper WP-800 OWNERSHIP STRUCTURE , PROFIT MAXIMIZATION , AND COMPETITIVE BEHAVIOR Govert Vroom. Business, 3, 0-41.

Mcconnell, J. J., \& Servaes, H. (1990). Additional evidence on equity ownership and corporate value *, 27, 595-612.

Mishra, R., \& Kapil, S. (2017). Effect of ownership structure and board structure on firm value: evidence from India. Corporate Governance: The International Journal of Business in Society, 17(4), 700-726.

Mohammed, A. M. (2018). The impact of ownership structure on firm performance: Evidence from Jordan. Academy of Accounting and Financial Studies Journal, 22(5). Retrieved from https://www.scopus.com/inward/record.uri?eid=2-s2.085057891130\&partnerID=40\&md5=8ab28fed8998785f5b8555529352a 206

Nguyen, T., Locke, S., \& Reddy, K. (2014). A dynamic estimation of governance structures and fi nancial performance for Singaporean companies. Economic Modelling, 40, 1-11. https://doi.org/10.1016/j.econmod.2014.03.013

Oliver, H. (1995). Corporate Governance: Some Theory and Implicatons. The Economic Journal, 105(430), 678-689. https://doi.org/10.2307/2235027

Perrini, F., Rossi, G., \& Rovetta, B. (2008). Does Ownership Structure Affect Performance ? Evidence from the Italian Market, 16(4), 312-325. https://doi.org/10.1111/j.14678683.2008.00695.x

Rathnayake, D. N., \& Sun, G. (2017). Corporate Ownership, Governance and Performance: Evidence from Asian Countries. Research Journal of Finance and Accounting Www.liste.Org ISSN, 8(15), 28-36. Retrieved from https://www.researchgate.net/publication/321480044

Saleh, A. S., Halili, E., Zeitun, R., \& Salim, R. (2017). Global Financial Crisis , Ownership Structure and Firm Financial Performance: An Examination of Listed Firms in Australia Article information :, (August). https://doi.org/10.1108/SEF-09-2016-0223

Schwartz-Ziv, M., \& Weisbach, M. S. (2013). What do boards really do? Evidence from minutes of board meetings. Journal of Financial Economics, 108(2), 349-366.

Sheikh, N. A., Wang, Z., \& Khan, S. (2013). The impact of internal attributes of corporate governance on firm performance: Evidence from pakistan. International Journal of Commerce and Management, 23(1), 38-55. https://doi.org/10.1108/10569211311301420

Shleifer, A., \& Vishny, R. W. (1997). A survey of corporate governance. The Journal of Finance, 52(2), 737-783.

Soufeljil, M., Sghaier, A., Kheireddine, H., \& Mighri, Z. (2016). Ownership structure and corporate performance: The case of listed Tunisian firms. Journal of Business \& Financial Affairs, 5(4), $1-8$. 
Stout, L. A., \& Blair, M. M. (2017). A team production theory of corporate law. In Corporate Governance (pp. 169-250). Gower.

Ullah, W., Ali, S., \& Mehmood, S. (2017). Impact of Excess Control , Ownership Structure and Corporate Governance on Firm Performance of Diversified Group Firms in Pakistan, 9(2), 49-72.

Uma, S., \& Roger, B. (2003). Research methods for business: A skill building approach. Book.

Wijethilake, C., Ekanayake, A., \& Perera, S. (2015). Board involvement in corporate performance: evidence from a developing country. Journal of Accounting in Emerging Economies, 5(3), 250-268.

World Bank, W. B. (2014). Building integrated markets within the East African Community: EAC opportunities in public-private partnership approaches to the region's infrastructure needs. The World Bank.

$\mathrm{Wu}, \mathrm{X} .$, \& Li, H. (2015). Board independence and the quality of board monitoring: Evidence from China. International Journal of Managerial Finance, 11(3), 308-328.

Zayed, A. (2017). Corporate Governance and Financial Firm Performance: Evidences from Jordan. Research Journal of Finance and Accounting Www.liste.Org ISSN, 8(10), 178-191. https://doi.org/10.1007/978-1-4899-7502-7_28-1

Zhou, H., Owusu-Ansah, S., \& Maggina, A. (2018). Board of directors, audit committee, and firm performance: Evidence from Greece. Journal of International Accounting, Auditing and Taxation, 31, 20-36. https://doi.org/10.1016/j.intaccaudtax.2018.03.002 